\title{
The Gold Cliché
}

\section{Ahmad Shauqi Zubir, Azwadi Ali}

\begin{abstract}
This study reports the findings from an extensive literature review on the factors that influence the prices of gold and the connections/interrelationships among global gold markets. Among other things, evidence observed from the literature review suggests that whilst there are seven main markets for gold across the world now, the prices of gold in the US and other markets do not have much impact on the prices of gold in the UK. The evidence also suggests that the impacts of the other factors like the exchange rate of the US dollar, inflation rate, interest rate, etc., on the price of gold are hard to quantify and use in a pricing model. Further, as more researches being published regarding gold factors, the newly discovered factors become intertwined with the factors that were discovered earlier by previous researches, hence complicates the explanation of gold factors.
\end{abstract}

Keywords: Gold markets, Gold prices, Gold factors, LBMA, COMEX, Gold futures, Gold mining, Gold demand and supply, Interest rate, Inflation rate, Currency, Gold ETF.

\section{INTRODUCTION}

The use of gold as a currency is back in the picture as this idea has been proposed during the 2019 International Conference on the Future of Asia in Tokyo (Lewis, 2019 and Latiff, 2019). Many see the reason behind this proposal as one of the clichés in financial market; gold is perceived as having the most stable price compared to any other commodities or financial instruments. The stability and factors influencing gold prices and values have long been studied by many researchers worldwide.

In describing the special features of gold in finance, especially in worldwide acceptance of its value, according to Baur and Lucey (2010), there is no robust explanation of why people accept gold as a safe shelter in preserving wealth. It is a common belief that gold may act as the safe shelter, maybe because of its role as money in ancient times or maybe because of traditional belief. Baur and Lucey (2010) also found that gold preserves its value when stock prices in certain countries are experiencing a downturn.

The investment in gold is also more profitable when compared to other assets. By using gold spot prices from 1970 to 2003, McCown and Zimmerman (2006) found that gold prices have no market exposure (zero-beta), with average return that is slightly higher than Treasury Bills. They also found that gold has an inflation-hedging ability. Their findings served as a great motivation for investors who are looking for a perfect shelter in preserving the value of their money. Treasury Bills have long been considered as a perfect investment as they are capable of enduring risk. The superiority against Treasury Bills is considered as their greatest achievement.

Revised Manuscript Received on June 13, 2020

* Correspondence Author

Dr. Ahmad Shauqi Haji Mohamad Zubir*, Lecturer, School of Business and Maritime Management, University Malaysia. E-mail: shauqi@umt.edu.my

Dr. Azwadi Ali, Associate Professor, School of Maritime Business and Management, University Malaysia. E-mail: azwadi@umt.edu.my

(C) The Authors. Published by Blue Eyes Intelligence Engineering and Sciences Publication (BEIESP). This is an open access article under the CC BY-NC-ND license (http://creativecommons.org/licenses/by-nc-nd/4.0/)
In comparing gold prices against money value, Reboredo (2013) used weekly data of gold prices from 7 January 2000 to 21 September 2012 in his study. By using copulas technique, he found that gold can be used as a hedging technique and a safe shelter against US Dollar movements. His finding is consistent with many previous seminal works which support the idea of using gold as a hedge or a safe shelter against the currency price changes. While many studies support the usage of gold to bear against stock market movements, inflation and currency depreciation, it is worth noting that the attractiveness of gold does not only apply to individuals. Central banks were reported to hold passive stockpiles of gold, without taking into account the patterns of gold prices (Aizenman and Inoue, 2013). Once more, this concludes the utility of gold in the financial system because of its vast worldwide recognition. It is also because gold is useful during difficult times, as it cannot be manipulated, unlike currency notes which can be printed if the central bank wants to interfere with its value. Aizenman and Inoue (2013) further conclude that this supports the idea that gold is a safe haven asset during economic downturn.

Further, gold has also resulted in the birth of other financial instruments such as gold stocks, gold futures and gold ETFs, among others. Not only that, gold is said to influence these financial instruments. For example, on 5 March 2014, investors become concerned about the prospect of their investment in the Canadian stock market because of the confrontation between Russia and Ukraine and the poor US private sector employment rate. The Toronto Stock Exchange at that time was given an unassuming lift as the stock values in the metal sector, especially gold increased as gold prices was also increased (Morrison, 2014). Beside financial instruments, gold is also said to be connected to economic indicators such as inflation, interest rate and currency exchange, among others. For example, the relationship between gold prices and inflation rate can be traced back to 1994 when Alan Greenspan, the US Federal Reserve ex-chairman, said that the gold price is not a pure indicator but "a very good indicator" of inflation and is used to forecast upcoming inflation (Ullmann, 1994).

Nevertheless, gold prices originate from gold transactions. Although most of gold transactions are done over the counter, there are seven places where gold markets are located and they are usually been used by previous researchers as references to the gold pricing ( $\mathrm{O}^{\prime}$ Connor et al., 2015). They are London, which the gold market there usually referred to as LBMA or London Fixing, New York (COMEX), Shanghai (Shanghai Exchanges), Tokyo (TOCOM), India (MCX), Dubai (Dubai Gold \& Commodities Exchange) and Istanbul (Borsa Istanbul AS). The pricing of gold in these gold markets is said to be influenced by many factors and these factors, alongside the connection between these gold markets, have drawn attentions from many researchers.

Published By:

Blue Eyes Intelligence Engineering 


\section{The Gold Cliché}

Not only that, the gold pricing in these markets are said to have a strong connection to the financial instruments and economic indicators mentioned earlier. Because of that, the purpose of this article is to explain and understand the factors that influence the gold prices. It is essential to explain what drives the gold prices as these same factors influence the pricing of the said financial instruments, and maybe the said economic indicators.

\section{II.GOLD MARKETS AROUND THE GLOBE AND THEIR CONNECTIONS}

As mentioned earlier, there are seven markets that can be considered as main gold markets in the world today (O'Connor et al., 2015). From those seven markets, the London Bullion Market Association (LBMA), London, United Kingdom can be considered as the main market based on turnover, followed by New York (O'Connor et al., 2015). Ferry (2016) added that the 'main market' for physical gold in the world is the LBMA and the 'market' itself is over-the-counter with the participants are only consist of five bullion banks. The number of participants or the participant itself may change from time to time. The banks agreed upon the daily prices of physical gold among themselves and their agreed prices are taken as benchmarks for physical gold prices globally. The price benchmarks are widely known as the London Fix. The other main market for gold is the Commodity Exchange, Inc (COMEX) which operates in New York, United States of America. COMEX trades metals which include gold and silver. The trading is based on gold futures and the closing prices of the futures are considered as benchmarks for gold spot prices. The dominance of LBMA and COMEX are highlighted by Lucey et al. (2013). That is, they regard LBMA and COMEX as the global biggest spot and futures markets for gold. The reason to that is, the LBMA, followed by COMEX, usually leads other gold market in gold pricing. This is also supported by the findings by Murray (2011).

According to Murray (2011) the two largest centres for gold trading in the world are the LBMA and COMEX futures, as $86 \%$ and $10 \%$ of the world's gold trading happens there, respectively. Not only that, Lucey et al. (2013) states that both markets influence other gold markets in terms of price discovery although no specific association in the sense of macroeconomic and politics can be found. They conclude that the LBMA is probably the dominant gold market by taking into account the existence of significant time variation. Further, Lucey et al. (2014) examine the returns and volatilities of four gold markets (London, New York, Tokyo and Shanghai), in searching for gold prices dominance. They provide an evidence that LBMA and COMEX are dominant in influencing other market's returns and volatilities.

The search for gold's market dominance is not new. In terms of gold market status and ranking, Laulajainen (1990) investigates three of them, each in New York, London and Hong Kong. The daily prices from a 24 hour trading were analysed from each of them by using a VAR model. The findings show that the gold prices from New York do affects the gold prices in London and Hong Kong, which conclude that the New York gold market is the dominant to the other two. However, the study only used PM Fixings (London Fixing that happens in the afternoon) and didn't consider AM Fixing (London Fixing that happens in the morning) at all. This can lead to the reliability problem of the data as the PM Fixings overlaps with the New York trading.

The relationship between TOCOM and COMEX gold markets has also been studied, specifically by $\mathrm{Xu}$ and Fung (2005). By analysing the data of gold prices from 1994 and 2001, they found that the gold prices returns in the US led the Japanese gold prices returns and the association between those two is symmetric, especially when volatilities are taken into account. The reliability of the findings is superior to the findings by Laulajainen (1990) as the prices from those two markets do not overlap. The findings from a more recent study by Jena et al. (2017) indicates that gold prices around markets worldwide do interact with each other. That is, the LBMA and COMEX lead other gold markets to a certain amount of time. Hence, they concluded that LBMA and COMEX serve as factors in determining the gold prices worldwide. Further, Yurdakul and Sefa (2017) deployed Engle-Granger and ARCH analysis and found that the LBMA gold prices as the only and most important factor to the gold prices worldwide. As a conclusion, based on previous findings, the main gold market in the world which is LBMA is not being influenced by other markets. This is because the determination of the gold prices in the UK is done by market makers which are bullion banks and that process is only unique in the UK. It doesn't involve other markets and the purpose of the process is to determine the gold prices in the UK. As has been argued by Ferry (2016), if the London Fixing is influenced by other gold markets such as COMEX, then the London Fixing itself is pointless and if that is the case, all of the market makers would have realised that. That is, they would just simply take the COMEX gold pricing as their reference instead of having their own.

\section{III.ANALYSIS AND RESULTS}

As been mentioned by Ferry (2016), one of the main factor that influences the gold pricing is the price of gold futures. This evidence can be seen in the COMEX and COMEX itself is referred to as one of the main market for gold. Hence, gold futures market serves as a place for price discovery for gold. In fact, gold futures is the main factor that drives the ups and down of gold in 1980 to 1982 as investigated by Mills (2004). As gold futures prices serve as the 'future' prices for gold, it is very common that the market makers and other people who involve in gold transaction use the gold futures prices as their reference in their bid and ask process (Hunsader et al., 2012, among others). Not only in COMEX, gold futures prices are also found to lead the gold prices in India, according to Pavabutr and Chaihetphon (2010). The reason for that is the same to what happens in COMEX. In the case of UK, although there are few researches done to connect between the gold prices and gold futures prices, the connection is inconclusive. The main reason is the LBMA. It determines the gold prices there and any other factor would be a less important than the LBMA (Harvey, 2013). For example, Caminschi and Heaney (2014) investigate the connection between gold futures in COMEX and LBMA. They found that the prices of gold futures in COMEX responds to the London Fixing process, although that process is done privately between the LBMA members which are bullion banks.

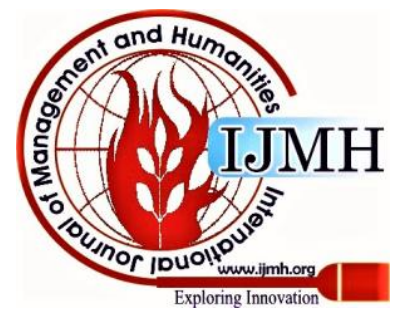


A robust explanation to such reaction from the gold futures in COMEX is not given by them, especially on how this can happen in the first place. On the other hand, it confirms the other studies which designate LBMA as the main dominant gold market in the world.

Other than gold futures, as similar to other commodities, the factor that determine the price of gold in different markets is the demand and supply of the gold itself. O'Connor et al. (2015) point out that gold demand mostly derives from investment and jewellery. The most significant gold demand in investment is in gold ETF (Baur, 2013a) while other gold investment such as coin and bullion have much smaller impact to the gold demand. Jewellery in the other hand, plays a consistent role in gold demand, although its amount varies from year to year. Other sources of gold demand come from production industries such as electronics and medicals. The effect of demand factor is also found to be nearly similar, that is negatively affecting the gold prices in the US, Japan, Germany, France, Italy, and the UK, as reported by Batchelor and Gulley (1995). Further, Starr and Tran (2008) found that in developed economies which include the US and the UK, gold demand increases when the per capita GDP increases. They assume that this is because gold is regarded as a discretionary expenditure in those countries, in which people buy gold when they have more money to spend. In other words, gold is considered as luxury items instead of necessities, unlike in certain countries where gold has a close tie to their traditional belief and way of life. Therefore, the connection between gold demand and gold prices is more obvious in the country with developed economy. Mozes and Cooks (2013) however, conclude that the demand of gold does not strongly influence the gold prices. This is based on their analysis through the 1992 to 2012 period which finds that the pattern of gold demand and gold prices differ and not similar in trends. In summary, there are times when the connection between gold demand and gold prices is strong, weak and there are times when there is no connection at all can be found between them. Hence, the former cannot be accredited to explain the latter, vice versa.

From the supply side, Feldstein (1980) claims that the gold sale by the central banks would affect the gold prices negatively and he offers a long explanation for his claim. In 1999, the Bank of England sold large amount of its gold holdings. The impact was the decreased of gold prices at that time and this is one of the evidences that support Feldstein (1980) claim. Also, previous investigation by Salant and Henderson (1978) found that gold sales announcement by central banks does affect gold prices in negative manner. Their research however, has been heavily criticised by O'Connor et al. (2015) as the methodology used is not reliable and valid in real world practice.

Other than gold sale by the central banks, the supply of gold also comes from gold mining (O'Connor, et al., 2015). Bertus and Stanhouse (2001) discuss the relationship between gold supply from the gold mining operations and gold prices. From their study, the relationship is sophisticated to be identified as it is hard to differentiate between the new gold investment (ETF, bullion and coin) and the newly mined gold. Because of that, the connection between newly mined gold, gold demand and gold prices is ambiguous. In other words, the exact amount of newly mined gold that was released to the market, being circulated to the economy and was offered to the investors is not known. Of course, one cannot tell whether his or her investment in gold ETF for example, consists of newly mined gold or not. The same goes with gold bullion and coin. Gold is gold and its price does not differ based on whether it is newly mined or not. Perhaps a different and reliable methodology, with certain limitations should be developed and used to tackle the issue.

On the other hand, Erb and Harvey (2013), Borenstein and Farrell (2007) and Blose and Shieh (1995) found no evidence of relationship between gold mining (supply) and gold prices, especially in developed economies. Data from other countries such as developing economies were not considered as they are scarce and unclear. In certain countries, the amount of gold mined is secretive and not available to the public. Nevertheless, Selvanathan and Selvanathan (1999) and Rockerbie (1999) found that the increase of gold prices would result in the increase of gold supply from the mining activity and not the other way around. The effect of gold prices however, takes many years to be detected in the gold supply. It is interesting to discuss the relationship between gold mining and gold prices. Rather, a couple of general questions should be asked and discussed before any investigation is carried out; Do the gold mining companies increase their output because of gold prices?; In the condition of bearish gold market, do the gold mining companies decrease their output or close their mining activity until the gold prices become bullish? Yet, the response from the gold mining companies to these questions have never been reported in any academic articles, just to avoid any speculative intention.

Apart from demand and supply, interest rate has also been heavily associated with gold prices by previous researchers. The logic behind that is if the interest rate is decreased, gold prices will go up as investors will choose other type of investment such as gold. Because of high demand, gold prices will go up and offer higher returns than interest rate. In other words, gold is an opportunity cost for interest rate. This is not entirely true though. For instance, Diba and Grossman (1984) conclude that interest rate do act as an opportunity cost for gold. Their study uses data in the US in the late $1970 \mathrm{~s}$ to early 1980s. They found that interest rates and gold prices do interact with each other, implicating that interest rate serve as a factor to gold and vice versa. However, that is not the case based on the findings by Lawrence (2003). By using a longer time span for the data, he found that the returns on gold is not significantly correlate with interest rates, inflation rates and GDP. On the other hand, returns from other investments based on other assets such as aluminium and zinc, and financial assets such as stock market indices and T-Bill do significantly correlate with interest rates, inflation rates and GDP. His findings is supported by Silva (2014). Other findings by Levin et al. (2006), Baur (2011) and Batten et al. (2014) are mixed, in which they found that the relationship between gold prices and interest rates varies according to the timing and time span of the data. The explanation is that other variables might have intervened or moderated the relationship between gold prices and interest rates during different times. Therefore, a purely and clear relationship between them cannot be established.

Published By:

Blue Eyes Intelligence Engineering

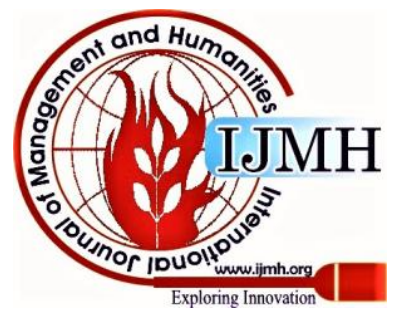

\& Sciences Publication

(C) Copyright: All rights reserved. 


\section{The Gold Cliché}

Inflation rate is also found to be having a relationship with gold prices. For instance, Silva (2014) concludes that inflation in the US is positively correlated to gold prices by using data in the 1970s and 1980s. This confirms the findings by Taylor (1998) who uses time series analyses such as cointegration and other long run tests to the data from 1914 to 1996 . The inflation rate is represented by the Consumer Price Index (CPI) in the US. Levin et al. (1994) and Levin et al. (2006) investigate and separate the relationship between inflation rate and gold prices to long run and short run. They found that the long run relationship is more obvious than the short run relationship between the inflation rate and the gold prices. Analysis of the inflation rate and gold prices by using structural breaks to eliminate the effect of hyperinflation era during 1970s in the US was done by Worthington and Pahlavani (2007). They found that gold prices can be used to hedge against inflation during the 1940s to 2000s era. Bampinas and Panagiotidis (2015) confirm that this is also the case in the UK.

Feldstein (1980), Fortune (1987) and Batten et al. (2014) demonstrate that the relationship between gold prices and inflation rate occurs because they both are related to the interest rates. As an evidence, gold prices and Consumer Price Index (CPI) do relate to each other according to their investigations but the relationship becomes weaker during 1980s to 1990s. The relationship however, improved during early 2000s, as pointed out by Batten et al. (2014). After a thorough examination, it is found that the reason for that is interest rates. That is, as interest rates decreased, the inflation rate increases as more money can be borrowed and circulated in the economy. Interest rates, as they suggest, is an opportunity cost for gold prices, vice versa. Hence, interest rate affects inflation rate and gold prices concurrently. This explanation however, can be challenged as that is not the case based on findings by Lawrence (2003), Levin et al. (2006), Baur (2011) and Silva (2014).

Inflation rate might have a 'unique' relationship or might impact gold prices due to many reasons, based on previous researches. The first one is gold has long been regarded as a 'global currency', especially during the gold standards era (O'Connor et al., 2015, among others). That is, many currencies have been linked to gold (Pukthuanthong and Roll, 2011) and as currencies react to inflation, there is a strong intuition that gold itself might react to inflation. Not only that, according to many previous researchers, for example Worthington and Pahlavani (2007), gold is accepted worldwide as it is a real, tangible and has its own widely complimented intrinsic value. Because of that, Fisher (1930) suggests that gold can be utilised as a wealth shelter against inflation rate. Thus, that suggestion serves as the second reason. Gold is also limited in amount and its production is also limited. Unlike fiat money, gold cannot be simply printed and circulated in the economy. Hence, the third reason is gold financial ability or purchasing power, cannot simply be decreased because of inflation and this is why gold is considered as a hedge against inflation (Van Hoang et al., 2016). Therefore, people will choose gold in the time of inflation and its demand will drive its prices up. The fourth reason is gold has been found to be responding quicker to news than consumer prices (Mahdavi and Zhou, 1997, among others). That of course is a sign that gold could lead inflation in the economy (Laurent, 1994; Garner, 1995; Ranson and Wainright, 2005), as if there are changes in inflation then there has already been changes to the gold prices. The fifth reason is gold is being used as one of the materials in production sector such as electronics, dentistry, medical, advance technology and aviation (Lawrence, 2003). Therefore, if inflation increases, prices of products from these sectors would also increase. This might decrease the demand of these products, hence the demand of gold. Also, if the gold prices increase, the prices of these products would also increase and this can lead to inflation (Van Hoang, et al., 2016). In the event of higher inflation, interest rates would be raised to appeal the investors or borrowers (Feldstein, 1980). As this happens, investors who are looking for a higher compensation would leave gold investment and buy notes or bonds (where interest rates is part of the deal). As a result, the required rate of return from gold investment or holdings would also be raised to 'counteract' the increased interest rates and the exodus of the investors. That is the sixth reason.

Apart from these reasons, Fortune (1987), Levin et al. (1994) and Levin et al. (2006) suggest a simpler explanation regarding the connection between inflation and gold prices. That is, if inflation increases, the costs related to gold exploration, mining, producing, processing and transportation would also increase, hence increasing the gold prices.

The next factor that is usually being associated with gold prices is the US Dollar currency. This argument stems from the fact that gold transaction usually involves US Dollar (O'Connor et al., 2015). Therefore, when the US Dollar depreciate against other currencies, gold becomes cheaper to other countries and demand will increase, as well as gold prices. In other words, US Dollar and gold prices are said to have negative relationship between them. Many previous literatures found such evidence to support this argument (Tully and Lucey, 2007; Sari et al., 2010, among others). Nevertheless, there are also researchers who find that this is not necessarily true. For example, Sjaastad and Scacciavillani (1996) argue that it is the European countries that controlled the global gold market based on their currencies and this is supported from their analysis of the effect of global currencies to the gold prices. On the other hand, Sjaastad (2008) conclude that currencies from the countries in which gold investment activity happens intensively do have significant effect on gold prices and top of that currencies hierarchy is the US Dollar. On the other note, Pukthuanthong and Roll (2011) suggest that the connection between the US Dollar and gold prices can only be found and proved in statistics but in real world, that is not the case. They show that the gold prices can be linked with any currencies that is depreciating, not only limited to US Dollar. The gold prices - US Dollar connection is actually based on 'popular' belief. Their argument is supported by O'Connor and Lucey (2012) by using different methodology. Therefore, these findings from these two articles have successfully show that the connection between the US Dollar and gold prices is not beyond any reasonable doubt. Gold is also influenced by investor's behaviour according to Aggarwal et al. (2014). That is, gold prices react based on the investor's perception regarding future outcome. The reaction varies in amount and direction (positive or negative) of the future path. This is in line with the findings by Smales (2014) and Smales and Yang (2015).

Published By:

Blue Eyes Intelligence Engineering 
Smales (2014) found that gold futures returns is highly effected by bad news, especially to the traders with net position. In addition, Smales and Yang (2015) found that gold prices decreased when good news are announced regarding macroeconomic condition. The good news are found to be statistically significant in explaining gold trading volume, volatility and returns. But then good news not only influencing gold prices. They are found to be influencing many others such as stock prices, firm's prospect and performance (Milgrom, 1981). Also, they are found to affect stocks, crude oil, interest rate, foreign exchange (Kurov and Stan, 2018) and others, which are also being heavily linked with gold prices. That is, the gold prices-investor behaviour connection is easy to be stated and it's anyone's guess, but to provide solid evidence is another issue. In other words, the relationship between gold prices and investor's behaviour is not really obvious and clear.

The factors that determine the gold prices are many and complicated to be identified according to $\mathrm{Li}$ and Chengmei (2013). This can be seen in many previous literatures in which many researchers have been trying to discover the factors from time to time. To sum up, the foundation of gold price is a very sophisticated economic procedure. Nevertheless, Li and Chengmei (2013) found that gold reserve, energy product, financial market and macroeconomic indicators do have significant relationship with gold prices, but not serve as pure factors. Kumar (2017) found that oil prices Granger caused gold prices while Harris and Shen (2017) identify USD rates as factor which determine gold prices. Gangopadhyay et al. (2016) however, identify USD rates, oil prices and financial markets as the factors driving gold prices. Other than that, Ariovich (1983) found that political tensions affect mostly the gold price in the US than any other market, due to the US Dollar that is being used as 'international currency' and gold price quotes.

Other than that, Ivanov (2011) found that gold ETF prices do affect the spot price of gold in New York. That is, gold ETF market serve as a market for price discovery for gold futures and gold itself. This is supported by the findings by Baur (2013a) that gold ETF introduction has increase the demand of gold as gold investment is more accessible, especially to the small investors. This happens as many gold ETF use physical gold and gold futures as their underlying assets. Hence, certain investors turn their heads to the gold ETF market as a reference to the gold pricing. Also, because of the easier access, gold ETF has become more popular in gold investment especially to the small investors and they consider that gold ETF investment as a gold investment (O'Connell, 2007). Not only that, Bernstein (2009) suggests that ETF introduction would affect significantly the trend of its underlying asset and the derivative instruments which also use the same underlying assets. This happens not only in gold ETF but also in other commodities ETF. The effect is that there is a shift in the dominance of price discovery between the ETF market, the underlying asset market and the futures market of that underlying asset, similar to the conclusion by Ivanov (2011) and Baur (2013a). So far, no such investigation is done in the UK market.

As many factors have been used in modelling gold prices and determining what are the factors that drives the gold prices, Baur and Glover (2015) suggest that many previous literatures actually have failed to identify the correct factors.
Instead, they only come out with what is categorised as 'factors that could be used for speculative purpose by certain investors' and not factors that actually guide the gold prices. The main reason for that is overspecification, a problem which can be found not only in gold literatures but also in other areas as well.

\section{IV.DISCUSSION AND CONCLUSION}

The relationship between gold market in the UK and gold market in the US can be determined by comparing the gold prices from those two markets. From the Gold Price Group (2017), it is found that the price for 1 oz gold is GBP974.10 in the UK and GBP974.86 in the US (prices for 14/11/2017 after currency exchange conversion). The price is pretty much the same. However, if an investor from the UK want to buy $1 \mathrm{oz}$ of gold, he better buys it from the UK market as the exchange rate does fluctuate and he would have to bear other costs such as transportation and insurance. That is, the gold price is not cheaper in other markets compared to the UK. In terms of returns, the daily return for the UK (between $13 / 11 / 2017$ and $14 / 11 / 2017$ ) is $0.18 \%$ while it is $0.05 \%$ in the US for the same period. This is because the gold price in the UK was cheaper than in the US on $13 / 11 / 2017$. However, there is no guarantee that this condition is true all the time.

Because of that, many studies have been undertaken to link between the gold prices in the UK to the other gold prices in other markets, not only the US. Majority found that gold prices in the UK and US markets influence other gold markets and there is no possibility of the other way around. Further, Jena et al. (2017), Yurdakul and Sefa (2017) and Ferry (2016) found that the UK gold market is the most dominant gold market in the world, which support the suggestion from Caminschi and Heaney (2014) that it is the LBMA that influences the gold prices in COMEX. The explanation to that is the LBMA itself which consists of market makers in the gold market, not only in the UK but also in the world. They are considered as market makers as they hold the majority of the gold stocks that can be circulated in the market, whether that gold belongs to them or to their clients (Ferry, 2016). As far as we know, there is no evidence that suggests that the gold prices in the UK is or was influenced by other gold markets.

As Jena et al. (2017), Yurdakul and Sefa (2017), Ferry (2016) and Caminschi and Heaney (2014) suggest, London Fixing process is like an auction market, but it is done privately between the market makers. Thus, what determines the agreed prices is anyone's guess, but for a start we know that it is the market makers. And the agreed prices serve as the gold prices for UK gold market. The need to determine its own gold prices is caused by the complications involving gold transactions. That is, taxes and other related costs, which are trickier when involving two countries like the US and the UK (Petroff, 2013). Further, if the gold currency exists in the near future, it is not something that is baseless if one assumes that it would be influenced by the pricing at the UK gold market. Hence, the idea of free, independent and stable currency would be shaken.

Other than gold market, there are factors that are said to be influencing the gold prices.

Published By:

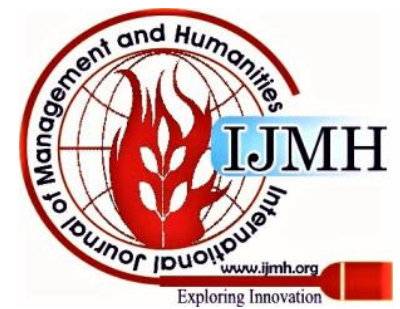




\section{The Gold Cliché}

They are gold futures prices, gold demand and supply, interest rate, inflation rate, US Dollar and others. If these factors do influence gold prices, then these same factors will influence the pricing of other financial instruments such as gold stocks, gold ETFs and if applicable, gold currency. However, based on previous findings, it is still inconclusive whether these factors influence gold prices or not. This is in line with $\mathrm{Li}$ and Chengmei (2013) and Baur and Glover (2015) suggestions that so far there is not even a single factor that can be regarded as obvious or pure factor that influences the gold prices and researchers are still struggling to find it. In addition, this conclusion would also destabilise the idea of having a stable currency via gold currency.

For a long term, it is still unknown that gold would be sufficient to be used by people either nationally or globally as a single currency. The reasons are the increased mining costs, exploration would decline, gold reserve of a country that is not sustainable and there are complications in finding new deposits, among other factors (Shafiee and Topal, 2010, among others). And if this situation remains with gold displaces fiat currencies, it would utilise as a deflationary force on the economy as the currency supply would not grow in tandem with the economy. This situation happened during late $19^{\text {th }}$ century where employees had to receive a decreased salary every year due to the nonflexible supply of money. As William Bryan once reminded us: "You shall not crucify mankind upon a cross of gold" (Kazin, 2006). Long before that, coin currencies have also been sacrificed because of their usefulness in other areas. During the Song Dynasty in China (960 - 1127 AD), the currency that were made from copper were melted to make weapons, hence caused a havoc on money supply at that time (Horesh, 2012). Besomi (2010) reported that England also had a problem with the precious metal supply during $1787 \mathrm{AD}$, hence announced that pound sterling cannot be converted into precious metal at that time.

\section{REFERENCES}

1. Aggarwal, R., Lucey, B. M. and O'Connor, F. A. (2014) Rationality in precious metals forward markets: Evidence of behavioural deviations in the gold markets. Journal of Multinational Financial Management, 25 - 26: $110-130$

2. Aizenman, J. and Inoue, K. (2013) Central banks and gold puzzles. $J$. Japanese Int. Economies, 28: 69 - 90

3. Ariovich, G. (1983) The impact of political tension on the price of gold. Journal for Studies in Economics and Econometrics, 16: 17 - 37

4. Bampinas, G. and Panagiotidis, T. (in press) (2015) Are gold and silver a hedge against inflation? A two century perspective. International Review of Financial Analysis [online]. Available from: http://www.sciencedirect.com/science/article/pii/S105752191500037X [Accessed 25 April 2015]

5. Batchelor, R. and Gulley, D. (1995) Jewellery demand and the price of gold. Resources Policy, 21: 37 - 42

6. Batten, J. A., Ciner, C. and Lucey, B.M. (2014). On the economic determinants of the gold-inflation relation. Resources Policy [online], 41: 101-108. Available from: http://www.sciencedirect.com/science/article/pii/S0301420714000312 [Accessed 10 January 2015]

7. Baur, D. G. (2011) Explanatory mining for gold: Contrasting evidence from simple and multiple regressions. Resources Policy, 36: 265 - 275

8. Baur, D. G. (2013a) Exchange-Traded Funds on Gold - A Free Lunch? http://ssrn.com/abstract=2297756 [Accessed 1 March 2014]

9. Baur, D. G. and Glover, K. J. (2015) Speculative trading in the gold market. International Review of Financial Analysis, 39: 63 - 71

10. Baur, D. G. and Lucey, B. M. (2010) Is gold a hedge or a safe haven? An analysis of stocks, bonds and gold. The Financial Review, 45 (2010): 217-229

11. Bernstein J (2009) Commodities ETFs: Diversification and hedging. ETFzone [online], Tuesday $22^{\text {nd }}$ December. Available from: FIRN Research Paper [online]. Available from:

http://www.etfzone.com/? [Accessed 10 December 2014]

12. Bertus, M. and Stanhouse, B. (2001) Rationale speculative bubbles in the gold futures market: An application of dynamic factor analysis. Journal of Futures Markets, 21: 79-108

13. Besomi, D. (2010) Paper money and national distress: William Huskisson and the early theories of credit speculation and crises. The European Journal of the History of Economic Thought, 17 (1): 49-85.

14. Blose, L. E. and Shieh, J. C. P. (1995) The impact of gold price on the value of gold mining stock. Review of Financial Economics, 4 (2): 125 $-139$

15. Borenstein, S. and Farrell, J. (2007) Do investors forecast fat firms? Evidence from the gold-mining industry. RAND Journal of Economics, 38: $626-647$

16. Caminschi, A. and Heaney, R. (2014). Fixing a leaky fixing: Shortterm market reactions to the London PM gold price fixing. Journal of Futures Markets, 34: 1003 - 1039

17. Diba, B. and Grossman, H. (1984) Rational bubbles in the price of gold. NBERWorking Paper: 1300, Cambridge: National Bureau of Economic Research

18. Erb, C.B. and Harvey, C.R. (2012). The Golden Dilemma. SSRN Electronic Journal [online]. Available from: http://papers.ssm.com/abstract=2078535 [Accessed 24 April 2015]

19. Feldstein, M. (1980) Inflation, tax rules, and the prices of land and gold. Journal of Public Economics, 14: 309 - 317

20. Ferry, E. (2016) Gold prices as material-social actors: The case of the London Gold Fix. The Extractive Industries and Society, 3 (2016): 82 85

21. Fisher, I. (1930) The Theory of Interest. New York: MacMillan

22. Fortune, J. N. (1987) The inflation rate of the price of gold, expected prices and interest rates. Journal of Microeconomics, 9 (1): 71 - 82

23. Gangopadhyay, K., Jangir, A. and Sensarma, R. (2016) Forecasting the price of gold: An error correction approach. IIMB Management Review, (2016) 28: 6 - 12

24. Garner, C. (1995) How useful are leading indicators of inflation? Economic Review, Federal Reserve Bank of Kansas City 80 (2): 1 - 18

25. Harris, R. D. F. and Shen, J. (2017) The intrinsic value of gold: An exchange rate-free price index. Journal of International Money and Finance, 79 (2017): 203 - 217

26. Harvey, R. (2013) "Market status/status markets: the London Gold Fixing in the Bretton Woods era." In Sandra Bott (ed.) The Global Gold Market and the International Monetary System from the Late 19th Century to the Present: Actors, Networks, Power. London: Palgrave McMillan. pp. 181 - 197

27. Horesh, N. (2012) From Chengdu to Stockholm: a comparative study of the emergence of paper money in east and west. Provincial China 4 (1): 68-99.

28. Hunsader, K., Javine, V. and Dickens, R. (2012) Exchange traded funds market reactions to option introduction. Banking and Finance Review [online], 4 (2): 71-84. Available from: http://www.scopus.com/inward/record.url?eid=2-s2.084874388617\&partnerID=tZOtx3y1

29. Ivanov, S. I. (2011) The Influence of ETFs on the Price Discovery of Gold, Silver and Oil. Journal of Economics and Finance, August 2011: 1-10

30. Jena, S., Tiwari, A. and Roubaud, D. (in press) (2017). Comovements of gold futures markets and the spot market: A wavelet analysis. Finance Research Letters [online]. Available from: http://www.sciencedirect.com/science/article/pii/S1544612317302271 [Accessed 15 November 2017]

31. Kazin, Michael (2006) A Godly Hero: The Life of William Jennings Bryan. New York: Alfred A. Knopf.

32. Kumar, S. (2017) On the nonlinear relation between crude oil and gold. Resources Policy, 51 (2017): 219 - 224

33. Kurov, A. and Stan, R. (2018) Monetary policy uncertainty and the market reaction to macroeconomic news. Journal of Banking \& Finance [online], 86: 127-142. Available from: https://www.sciencedirect.com/science/article/pii/S0378426617302194 [Accessed 8 November 2017]

34. Latiff, R. (2019) Malaysia's Mahathir proposes common East Asia currency pegged to gold [online]. Available from: https://www.reuters.com/article/us-malaysia-currency/malaysiasmahathir-proposes-common-east-asia-currency-pegged-to-goldidUSKCN1T00FX [Accessed 29 June 2019]

35. Laulajainen, R. (1990) Gold price round the clock. Resources Policy, 16: $143-152$

Published By:

Blue Eyes Intelligence Engineering 
36. Laurent, R. D. (1994) Is there a role for gold in monetary policy? Economic Perspectives, The Federal Reserve Bank of Chicago XVIII:2 $-14$

37. Lawrence, C. (2003) Why is gold different from other assets? An empirical investigation. World Gold Council [online], March 2003. Available

https://www.gold.org/download/file/2939/C_Lawrence.pdf [Accessed 10 October 2017]

38. Levin, E. J., Montagnoli, A. and Wright, R. E. (2006) Short-run and long-run determinants of the price of gold. World Gold Council [online], June $2006 . \quad$ Available from: https://www.gold.org/download/file/2941/rs_32_shortandlongrun.pdf [Accessed 10 October 2017]

39. Levin, E., Abhyankar, A. and Ghosh, D. (1994) Does the gold market reveal real interest rates? The Manchester School, 62 (1): 93 -103

40. Lewis, N. (2019) Mahathir's Asian Gold Currency Is A Return To Asian Values [online]. Available from: https://www.forbes.com/sites/nathanlewis/2019/06/18/mahathirs-asiangold-currency-is-a-return-to-asian-values/\#1744a4363870 [Accessed 29 June 2019]

41. Li, L. and Chengmei, D. (2013) Research of the Influence of MacroEconomic Factors on the Price of Gold. Procedia Computer Science, 17 ( 2013 ): 737 - 743

42. Lucey, B. M., Larkin, C. and O'Connor, F. A. (2013). London or New York: Where and when does the gold price originate? Applied Economics Letters, 20: 813 - 817

43. Lucey, B. M., Larkin, C. and O'Connor, F. A. (2014) Gold markets around the world - Who spills over what, to whom, when? Applied Economics Letters, 21: 887 - 892

44. Mahdavi, S. and Zhou, S. (1997). Gold and commodity prices as leading indicators of inflation: tests of long-run relationship and predictive performance. Journal of Economics and Business, 49 (5): $475-489$

45. McCown, J.R. and Zimmerman, J.R. (2006) Is gold a zero-beta asset? Analysis of the investment potential of precious metals [online] Available from: http://ssrn.com/abstract=920496 [Accessed 9 January 2014]

46. Milgrom, P. R. (1981) Good News and Bad News: Representation Theorems and Applications. The Bell Journal of Economics, 12 (2): $380-391$

47. Mills, T. C. (2004) Statistical analysis of daily gold price data. Physica A 338 (3-4): 559 - 566

48. Morrison, M. (2014) TSX sees modest gains, as dollar rises, BoC leaves interest rate at $1 \%$ [online]. Available from: http://www.ctvnews.ca/business/tsx-sees-modest-gains-as-dollar-risesboc-leaves-interest-rate-at-1-1.1714658 [Accessed 7 March 2014]

49. Mozes, H. A. and Cooks, S. (2013) The disconnect between physical gold demand and gold prices. The Journal of Wealth Management, 16: $112-121$

50. Murray S. (2011) LOCO London liquidity survey. Alchemist, 63: 9 10

51. O' Connor, F.A. and Lucey, B. M. (2012) Gold's negative relationship to the US dollar. The Alchemist, 66: 16

52. O' Connell R. (2007) Gold exchange traded funds: their evolution and their role. Inst Invest, 41: 129-135

53. O’Connor, F. A., Lucey, B. M., Batten, J. A. and Baur, D. G. (2015) The financial economics of gold - A survey. International Review of Financial Analysis [online], 41: 186-205. Available from: http://www.sciencedirect.com.ezproxye.bham.ac.uk/science/article/pii/ S1057521915001325?np=y\&npKey=99eed6593df1ce3d5d0cde74d6aa ec21113b78f1f01ad51af43a7001fa7af4bf [Accessed 15 April 2017]

54. Pavabutr, P. and Chaihetphon, P. (2010) Price discovery in the Indian gold futures market. Journal of Economics and Finance, 34: 455 - 467

55. Petroff, A. (2013) Taxes and ETFs: A Guide for British Investors. A Q\&A session with IFA Lee Robertson from Investment Quorum about ETFs and taxes for UK investors [online]. Available from http://www.morningstar.co.uk/uk/news/69342/taxes-and-etfs-a-guidefor-british-investors.aspx [Accessed 6 March 2014]

56. Pukthuanthong, K. and Roll, R. (2011) Gold and the Dollar (and the Euro, Pound, and Yen). Journal of Banking and Finance, 35: 2070 2083

57. Ranson, D. and Wainright, H. C. (2005). Why gold, not oil, is the superior predictor of inflation - USA - November 2005. [online]. South Hamilton: World Gold Council. Available from: https:/www.gold.org/research/why-gold-not-oil-superior-predictorinflation [Accessed 1 November 2014]

58. Reboredo, J. C. (2013) Is gold a safe haven or a hedge for the US dollar? Implications for risk management. Journal of Banking \& Finance, 37 (2013): 2665 - 2676
59. Rockerbie, D. W. (1999) Gold prices and gold production evidence for South Africa. Resources Policy, 25: 69 - 76

60. Salant, S. W. and Henderson, D. W. (1978) Market anticipations of government policies and the price of gold. The Journal of Political Economy, 86: 627 - 648

61. Sari, R., Hammoudeh, S. and Soytas, U. (2010) Dynamics of oil price, precious metal prices, and exchange rate. Energy Economics, 32: 351 362

62. Selvanathan, S., and Selvanathan, E. A. (1999) The effect of the price of gold on its production: A time-series analysis. Resources Policy, 25 $265-275$

63. Shafiee, S. and Topal, E. (2010) An overview of global gold market and gold price forecasting. Resources Policy, 35 (2010): 178 - 189

64. Silva, E. S. (2014) Forecasting the price of gold. Atlantic Economic Journal, 14: $43-52$

65. Sjaastad, L. A. (2008) The price of gold and the exchange rates: Once again. Resources Policy, 33: 118 - 124

66. Sjaastad, L. A. and Scacciavillani, F. (1996) The price of gold and the exchange rate. Journal of International Money and Finance, 15: 879 897

67. Smales, L. A. (2014) News sentiment in the gold futures market. Journal of Banking \& Finance, 49: 275 - 286

68. Smales, L. A. and Yang, Y. (2015) The importance of belief dispersion in the response of gold futures to macroeconomic announcements. International Review of Financial Analysis, 41: 292 - 302

69. Starr, M. and Tran, K. (2008) Determinants of the physical demand for gold: Evidence from panel data. The World Economy, 31: 416 - 436

70. Taylor, N. J. (1998) Precious metals and inflation. Applied Financial Economics, 8 (2): 201 - 210

71. Tully, E. and Lucey, B. M. (2007) A Power GARCH Examination of the Gold Market. Research in International Business and Finance, 21 (2): 316-325

72. Ullmann, O. (1994) Why Greenspan Has A Touch Of Gold Fever. Bloomberg Businessweek [online], Sunday $6^{\text {th }}$ March 1994. Available from: http://www.businessweek.com/stories/1994-03-06/whygreenspan-has-a-touch-of-gold-fever [Accessed 8 March 2014]

73. Van Hoang, T. H., Lahiani, A and Heller, D. (2016) Is gold a hedge against inflation? New evidence from a nonlinear ARDL approach. Economic Modelling, 54 (2016): 54 - 66

74. Worthington, A.C. and Pahlavani, M. (2007) Gold investment as an inflationary hedge: cointegration evidence with allowance for endogenous structural breaks. Applied Financial Economics Letter, (3): $259-262$

75. Xu, X. E. and Fung, H-G (2005) Cross-market linkages between US and Japanese precious metals futures trading. Journal of International Financial Markets Institutions and Money, 15: 107 - 124

76. Yurdakul, F. and Sefa, M. (2015) An Econometric Analysis of Gold Prices in Turkey. Procedia Economics and Finance, 23 (2015): 77 - 85

\section{AUTHOR PROFILE}

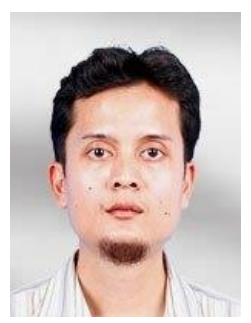

Dr. Ahmad Shauqi Haji Mohamad Zubir PhD (Birmingham), MSc Quantitative Sc. (Fin Eng) (UiTM), BSc (Hons) Act. Sc. (UKM)

Lecturer

Email: shauqi@umt.edu.my | Phone:+609 6683794 Dr. Ahmad Shauqi Bin Haji Mohamad Zubir is a finance lecturer at the School of Business and Maritime Management, Universiti Malaysia Terengganu (UMT), with more than 10 years teaching experience in the field. He holds a PhD in finance from the University of Birmingham. He was an affiliate of Registered Financial Planner, Malaysian Financial Planning Council and also a finance officer before taking the role as a lecturer at UMT. His main research interest includes mathematical and econometrical modelling in finance, profitability analysis of financial assets and transactions, practicality of Islamic economics and finance, and investment evaluation and analysis.

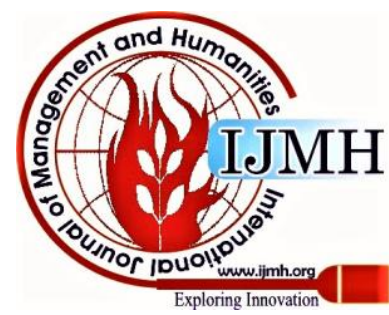


The Gold Cliché

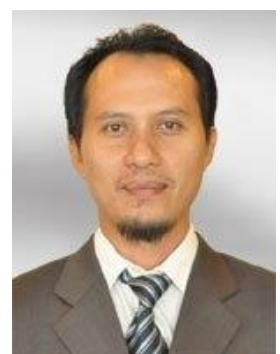

Dr. Azwadi Ali

PhD (Victoria), MAcc (UiTM), BA (Hons) Acc

\& Fin (Lancaster)

Associate Professor | Chairman of the Bachelor

of Accounting Programme

Email: azwadi@umt.edu.my |Phone: +609

6683449Dr.

Azwadi Ali is an associate professor at the School of Maritime Business and Management,

Universiti Malaysia Terengganu. He holds a

Bachelor of Accounting and Finance from Lancaster University (UK), a master's degree in Accountancy from UiTM, and a Ph.D. from Victoria University (Australia). He has taught mainly Accounting Information Systems and finance-related subjects at the school for more than ten years. His research interests include personal finance and accounting information systems (user perspective). He has published his research works in a number of journals and has been appointed as graduate thesis examiner, both inside and outside UMT.

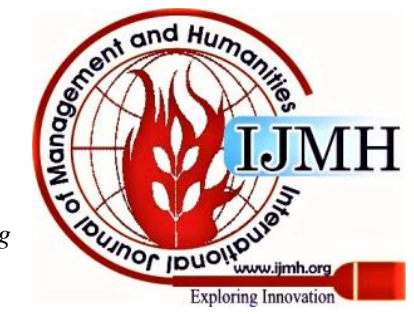

